\title{
Production and physicochemical properties of labneh anbaris, a traditional fermented cheese like product, in Lebanon
}

\author{
Ossama Dimassi ${ }^{1 *}$, Youmna Iskandarani ${ }^{1}$, Michel Afram ${ }^{2}$, Raymond Akiki ${ }^{3}$, \\ Mohamed Rached ${ }^{4}$
}

\author{
${ }^{1}$ Department of Nutrition and Food Science, Lebanese International University, Beirut, Lebanon \\ ${ }^{2}$ Lebanese Agriculture Research Institute, Bekaa - Tal Amara, Lebanon \\ ${ }^{3}$ Department of Business Administration, Lebanese International University, Beirut, Lebanon \\ ${ }^{4}$ Department of Biomedical Sciences, Lebanese International University, Beirut, Lebanon \\ *Corresponding author: odimassi@ gmail.com
}

\begin{abstract}
The aim of this study is to explore labneh anbaris production and physicochemical properties in Lebanon. Traditionally, it was done to preserve leftover milk by addition of salt and following naturalfermentation in an earthenware-vessel to produce a cheese like dairy product. In Lebanon there is 86 active dairy industries, of which only 7 produce Anbaris; annotated as industrial anbaris (IA) in this study. Eighty one household anbaris samples were collected from 16 locations distributed among one governate, Baalbek-Hermel (BHA), and two districts, Shouf (SHA) and Western-Beqaa (WBA). Water activities of anbaris were higher than 0.954. Total solids of WBA are significantly the lowest with values from IA, BHA and SHA did not differ significantly from each other. Milk to anbaris conversion values, $\mathrm{kg}$-milk/kg-anbaris of WBA was significantly the highest. WBA and BHA had significantly the highest titratable acidity and the lowest $p H$. The salt content did not differ significantly among anbaris from household and industrial origin. The fat value of WBA was significantly the lowest. Protein content did not differ significantly. Anbaris can be classified as full fat, soft, fermented type of cheese from raw milk. The variation in physicochemical attributes, between the regions and origin of anbaris, necessities further studies to better assess the factors affecting anbaris production. The low pH (3.76) renders this product shelf stable against bacterial spoilage and has big potential to reduce the waste in the milk industry.
\end{abstract}

Keywords - Labneh, Anbaris, fermented cheese like product, traditional dairy products.

\section{INTRODUCTON}

Fermentation, especially for food of dairy origins, is one of the oldest methods of preservation known to mankind [1]. Fermentation ensures longer shelf life and microbiological safety of a food and in some, make food more digestible and in the case of cassava it reduces toxicity of the substrate [2]. Lactic acid fermentation is widely used during the manufacture of fermented dairy products. Such a fermentation process is the result of the presence of micro-organisms (bacteria, molds, yeasts or combination of these) and their enzymes in milk [3].

Bag or strained type products are manufactured in different countries such as laban zeer in Egypt, Besa in Bulgaria, skyr in Iceland, labneh and labneh anbaris or yogurt cheese in the Middle East and chakka and shrikhand in India,
Than or Tan in Armenia and Ymer in Denmark [4] [5]. Labneh which is a very popular food in Lebanon and is traditionally prepared by straining yoghurt using a cloth bag for several hours ending with a product containing around $25 \%$ total solid, slightly acidic, thick and creamy but smooth consistency [6]. The higher acidity is due to the concentration of lactic acid produced by the uninterrupted fermentation [7]. Usually Labneh is stored in the refrigerator to retard fermentation and spoilage [8]. For longer storage purposes, Labneh is made into small balls and slightly dehydrated to be placed in jars and covered fully in vegetable oil. This method can help keep the product for more than twelve months [7].

Labneh Anbaris, a traditional cheese-like fermented dairy product, was prepared from cow's and goat's milk 
following natural fermentation of raw milk in earthenware vessel at around $30{ }^{\circ} \mathrm{C}$ for 7 - 15 days with continuous draining of whey and addition of raw milk and salt to repeat the whole process until the earthenware vessel is full [9] [10]. No starter culture is added because raw milk is employed, nor $\mathrm{CaCl}_{2}$ solution to assist curdling of milk [10]. Traditionally, this type of Labneh preparation process is during the warm weather season starting at the end of March and is carried on till September [9]. The end product is recovered in September as a very concentrated and highly acidic type of Labneh. It is consumed fresh or made into small balls and submerged in vegetable oil in jars to be consumed later.

Very few studies are done on this type of yogurt fermented cheese and those done like Serhan et al. studied the end product produced in the lab and took only two locations per cheese type [10]. Saleh studied this at 1991 but only simulated the process and did no survey of anbaris in the market [9]. Baraket, who studied the effect of heat treatment and storage on the microbiological and chemical qualities of anbaris, also studies sample done in the lab and took it from a food safety perspective [11]. No studies were found in Lebanon screening the anbaris from different regions. This is important to set the baseline information for future research on this traditional cheese-like fermented cheese that was done to prevent wastage of a very perishable product namely milk.

\section{MATERIALS AND METHODS}

\subsection{Anbaris samples}

In our study, after inquiring about household anbaris production the different governates in Lebanon by asking non governmental organizations interested in traditional Lebanese food such as Food Heritage organization and people from all governates, one governate and two districts were found to produce household anbaris. From these, 81 household anbaris samples (Table 1) were collected from 16 different locations (Fig. 1).

Household samples are sorted according to region: anbaris from Baalbek-Hermel Governate (BHA), anbaris from Wetern Beqaa District (WBA) and anbaris from Shouf District (SA)

Furthermore, the chambers of commerce in Lebanon are , Tripoli and North Lebanon, Saida and South Lebanon, Zahle and Beqaa, Beirut and Mount Lebanon. According to them there are 1498 registered food industries and from them 86 are involved in dairy production [12] (Fig. 2). A total of 21 samples were collected from the 7 out of 86 who produce anbaris in regular basis and annotated them as anbaris from Industrial origin (IA).

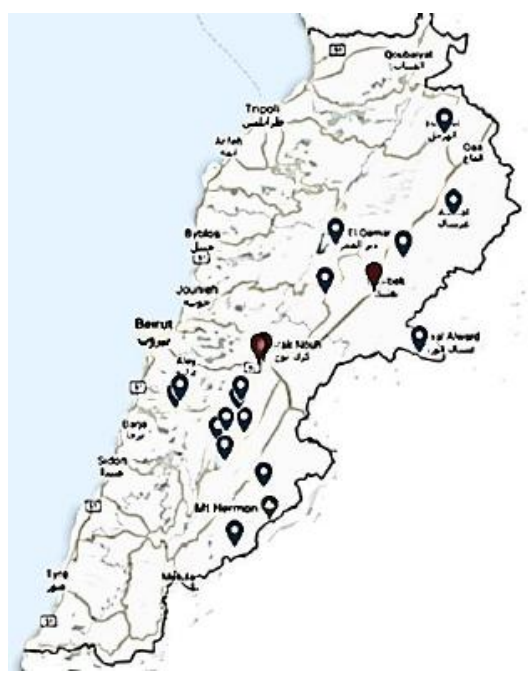

Fig.1 Location of anbaris samples collected in Lebanon

- Map was developed using my map application in google

\section{Distribution of dairy industry in lebanon}

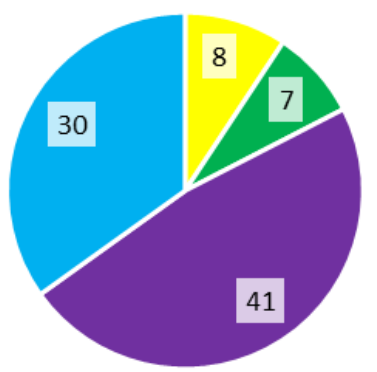

Tripoli and North Lebanon $=$ Saida and South Lebanon
Zahlee and the Beqaa

Fig. 2 Dairy producers in Lebanon per the corresponding chambers of commerce

Anbaris samples from different origin had a total of 102 samples, with 21 from the industry, 42 from Baalbek Hermel governate and ending with 12 sample from Shouf district (Table 1).

Table 1 Distribution of household anbaris samples and numberof anbaris from industrial origin

\begin{tabular}{lc}
\hline Anbaris Origin & Number Of Samples \\
\hline Industrial & 21 \\
Baalbek-Hermel & 42 \\
Western-Beqaa & 27 \\
Shouf & 12 \\
\hline Total & 102 \\
\hline
\end{tabular}




\subsection{Physicochemical properties determination}

Moisture content: Drying Oven and Balance method was used for moisture content determination. The oven used was Contherm designer series (Contherm Scientific LTD) following the ISO 5537:2004 [13].

Fat Determination: The fat content was determined using Soxhlet method as described by AOAC 922.06. [14]

Protein Determination: Protein content was determinedusing the Kjeldahl method according to AOAC 991.20. [14]

Ash Determination: Ash was determined using the AOAC 942.05 method. [14]

Weight determination: Weight was measured using Portable electronic balance Model 727 was used to measure the weight with an accuracy of \pm 1 gr (Jata Hogar).

pH: Microcomputer based pH /conductivity /TDS /salinity and temperature pocket meter Model $\mathrm{pH} / \mathrm{EC} 80$ was used to measure the $\mathrm{pH}$ (Jenco VisionP).

Titratable Acidity: TA is expressed as percent lactic acid and is determined by titration of a known amount of reconstituted milk with $0.1 \mathrm{~N} \mathrm{NaOH}$ using phenolphthalein as indicator [15].

Water activity: It was determined using Pawkit water activity meter. Samples were flattened to cover the bottom of the cup and then water activity was measured at room temperature [16].

Salt: It was determined using Chloride QuanTab® ${ }^{\circledR}$ Test Strips, 30-600 mg/L, Hach Company, Loveland, Colorado USA [17].

Milk to anbaris conversion value: were given by the 102 participants and validated by looking at the total solids in the anbaris.

Fat in Dry Matter (FDM) : Calculated by dividing the Fat percent by total sold percent (Eq. 1) [18]

Equation 1

$\mathrm{FDM}=$

Percent Fat

\section{Total Solid Percent}

Moisture on Fat Free Basis (MFFB): Calculated by dividing moisture percent by 100 minus Fat percent (Eq.2) [18]

Equation 2

$\mathrm{MFFB}=$

Percent Moisture

100-Percent Fat

\subsection{Microbiology}

Fractions of anbaris (10 g) were homogenized in $90 \mathrm{ml}$ peptone water (Himedia, Mumbia, India) with a laboratory blender (Waring Blender Lextra 2 Speed, USA) for 3 min. The suspension was subjected to serial decimal dilutions up to $10-8$ in $0.1 \%$ sterile peptone water and microbiological analyses were performed by using pour plate and spread plate methods according to ISO standards (Table. 2).

Table 2 Microbiological tests and the code of the reference methods

\begin{tabular}{|c|c|c|}
\hline Microbiology tests & $\begin{array}{l}\text { Reference } \\
\text { Method }\end{array}$ & Reference \\
\hline Aerobic Plate Count & ISO 4833:2016 & [19] \\
\hline Enterobacteriacae & $\begin{array}{l}\text { ISO } \\
2: 2017\end{array}$ & {$[20]$} \\
\hline Coliforms & ISO 4832:2006 & {$[21]$} \\
\hline E.coli & $\begin{array}{l}\text { ISO } \\
2: 2001\end{array}$ & {$[22]$} \\
\hline S. aureus & ISO 6888-1:1999 & {$[23]$} \\
\hline $\begin{array}{l}\text { Anaerobic Sulfite- } \\
\text { Reducing Bacteria }\end{array}$ & ISO 15213:2003 & {$[24]$} \\
\hline Clostridium perifringens & ISO 7937:2004 & {$[25]$} \\
\hline Listeria monocytogens & $\begin{array}{l}\text { ISO } \\
1: 2017\end{array}$ & [26] \\
\hline Salmonella & ISO 6579:2017 & [27] \\
\hline Yeast and Molds & ISO 6611:2004 & {$[28]$} \\
\hline
\end{tabular}

Anbaris industrial producers tested all samples since it is a requirement. Half of the household anbaris samples were tested as shown in the table below (Table 3). One third of the samples per region were randomly selected. This was done due to funding restrictions.

Table 3 Number of samples that were microbiologically evaluated

\begin{tabular}{lc}
\hline Anbaris Origin & Number Of Samples \\
\hline Industrial & 21 \\
Baalbek-Hermel & 15 \\
Western-Beqaa & 10 \\
Shouf & 5 \\
\hline Total & 51 \\
\hline 2.4. Statistical analysis
\end{tabular}

All tests and analysis were run in triplicates. General linear model performed via SPSS (statistical Package for the Social Sciences, version 17.0) was used to study the 
difference between the physicochemical properties of the anbaris based on sample origion. Tamhane test was used for mean separation of the physicochemical properties.

Furthermore, partial correlation was applied between the different physicochemical properties and the $\mathrm{kg}$ milk to $\mathrm{kg}$ anbaris conversion values taking origion and region of the anbaris as the control variable.

\section{RESULTS}

\subsection{General information about Industrial and household} anbaris production

None of the board of dairy producers, composed of the top 6 dairy producers in Lebanon [29], produces anbaris on large commercial scale. Seven producers out of the 86 do produce anbaris. All household and industrial producers use small portion of anbaris as the inoculation carrier to starter media (weight:weight) using raw unpasteurized milk. Furthermore, the 7 industrial anbaris producers have noted that anbaris labneh should be sour and have a granulated texture in comparison to the smooth creamy texture of labneh [5]. Furthermore, people might eat anbaris from the vessel during production and then add milk and salt again.

\subsection{Physicochemical}

\subsubsection{Water Activity and moisture content}

The water activity of the anbaris from Western Beqaa had the significantly lowest water activity compared to anbaris from other household from different geographical locations and industrial origin, which in turn did not differ significantly from each other (Table 4).

Table 4 Water activity and moisture content of anbaris

\begin{tabular}{lcc}
\hline & $\begin{array}{c}\text { Water Activity } \\
\text { Mean } \pm \text { SE }\end{array}$ & $\begin{array}{c}\text { Moisture \% } \\
\text { Mean } \pm \text { SE }\end{array}$ \\
\hline IA & $0.966 \mathrm{a} \pm 0.001$ & $58.76 \mathrm{a} \pm 1.77$ \\
BHA & $0.962 \mathrm{a} \pm 0.001$ & $58.22 \mathrm{a} \pm 1.16$ \\
WBA & $0.954 \mathrm{~b} \pm 0.001$ & $66.12 \mathrm{~b} \pm 1.54$ \\
SA & $0.964 \mathrm{a} \pm 0.002$ & $55.19 \mathrm{a} \pm 2.17$ \\
\hline
\end{tabular}

- Within Columns, means with different alphabets are significantly different.

- I: Industrial, A: Anbaris, BH:Baalbek-Hermel; WB: Western Beqaa, S: Shouf

As for the moisture content, household anbaris from Western-Beqaa district were significantly the highest when compared to anbaris from industrial origin and other household samples namely Baalbek-hermel and Shouf areas (Table 4).

\subsubsection{Anbaris Total Solids and conversion values}

The total solids and the milk to anbaris conversion values (kg milk/kg anbaris) were significantly the lowest in the Western beqaa district compared to those values obtained from Baalbek-Hermel and Shouf locations. Furthermore, it was also significantly lower than total solids and milk to anbaris conversion values ( $\mathrm{kg}$ milk/kg anbaris) from industrial origin (Table 5).

Table 5 Total Solids and milk to anbaris conversion values

\begin{tabular}{lcc}
\hline & $\begin{array}{c}\text { Total Solid } \\
\text { Mean } \pm \text { SE }\end{array}$ & $\begin{array}{c}\mathrm{Kg} \text { Milk / Kg Anbaris } \\
\text { Mean } \pm \text { SE }\end{array}$ \\
\hline IA & $41.24 \mathrm{a} \pm 1.77$ & $5.09 \mathrm{a} \pm 0.22$ \\
BHA & $41.78 \mathrm{a} \pm 1.16$ & $5.16 \mathrm{a} \pm 0.14$ \\
WBA & $33.88 \mathrm{~b} \pm 1.54$ & $4.18 \mathrm{~b} \pm 0.19$ \\
SA & $44.81 \mathrm{a} \pm 2.17$ & $5.53 \mathrm{a} \pm 0.27$
\end{tabular}

- Within Columns, means with different alphabets are significantly different.

- I: Industrial, A: Anbaris, BH:Baalbek-Hermel; WB: Western Beqaa, S: Shouf

\subsubsection{Titratable acidity (TA) and $\mathrm{pH}$}

The titratable acidity of the household anbaris from Shouf area is significantly the lowest compared to the other household anbaris from Baalbek-Hermel and WesternBeqaa areas and did not differ significantly from the TA of anbaris from industrial origin. Household anbaris from Baalbek-Hermel and Shouf had significantly higher TA values compared to that from industrial origin, while they did not differ significantly from each other (Table 6).

The $\mathrm{pH}$ values did not show clear trend in the significant difference between the household anbaris origin and that of industrial origin. The $\mathrm{pH}$ value of anbaris from WesternBeqaa region did not differ significantly from those of Baalbek-Hermel region and those of industrial origin. But it was significantly lower than that of Shouf region. The $\mathrm{pH}$ of anbaris from the shouf region in turn did not differ significantly from that of Baalbek-Hermel area and that of industrial origin (Table 6).

\subsubsection{Ash and salt content}

The ash content of anbaris from the Shouf region was significantly the lowest when compared to those values of household anbaris from Baalbek-Hermel and Western Beqaa region and anbaris from industrial origin (Table 7). 
Table 6 Titratable acidity and $\mathrm{pH}$ of anbaris

\begin{tabular}{lcc}
\hline & $\begin{array}{c}\text { Titratable Acidity } \% \\
\text { Mean } \pm \text { SE }\end{array}$ & $\begin{array}{c}\mathrm{pH} \\
\text { Mean } \pm \mathrm{SE}\end{array}$ \\
\hline IA & $1.58 \mathrm{a} \pm 0.06$ & $3.69 \mathrm{ab} \pm 0.04$ \\
BHA & $2.11 \mathrm{~b} \pm 0.04$ & $3.72 \mathrm{ab} \pm 0.04$ \\
WBA & $2.28 \mathrm{~b} \pm 0.13$ & $3.58 \mathrm{~b} \pm 0.05$ \\
SA & $1.51 \mathrm{a} \pm 0.18$ & $3.89 \mathrm{a} \pm 0.07$ \\
\hline
\end{tabular}

- Within Columns, means with different alphabets are significantly different.

- I: Industrial, A: Anbaris, BH:Baalbek-Hermel; WB: Western Beqaa, S: Shouf

Table 7 Ash and salt content and $\mathrm{pH}$ of anbaris

\begin{tabular}{lcc}
\hline & $\begin{array}{c}\text { Ash \% } \\
\text { Mean } \pm \text { SE }\end{array}$ & $\begin{array}{c}\text { Salt\% } \\
\text { Mean } \pm \text { SE }\end{array}$ \\
\hline IA & $5.80 \mathrm{a} \pm 0.57$ & $2.22 \mathrm{a} \pm 0.18$ \\
BHA & $6.89 \mathrm{a} \pm 0.42$ & $2.71 \mathrm{a} \pm 0.13$ \\
WBA & $5.47 \mathrm{a} \pm 0.45$ & $2.49 \mathrm{a} \pm 0.16$ \\
SA & $3.17 \mathrm{~b} \pm 1.27$ & $2.85 \mathrm{a} \pm 0.26$ \\
\hline
\end{tabular}

- Within Columns, means with different alphabets are significantly different.

- I: Industrial, A: Anbaris, BH:Baalbek-Hermel; WB: Western Beqaa, S: Shouf

The salt content of all the anbaris samples from different household origin and those from industrial one did not differ significantly from each other (table 7).

\subsubsection{Fat and protein content}

The fat and protein content of anbaris from Western Beqaa region were significantly the lowest compared to values of anbaris other household regions, Baalbek Hermel and Shouf, and those from industrial origin (Table 8).

Table 8 Fat and protein content and $\mathrm{pH}$ of anbaris

\begin{tabular}{lcc}
\hline & Fat $\%$ & Protein $\%$ \\
& Mean \pm SE & Mean \pm SE \\
\hline IA & $21.23 \mathrm{a} \pm 0.99$ & $21.03 \mathrm{a} \pm 1.66$ \\
BHA & $19.26 \mathrm{ab} \pm 0.65$ & $19.22 \mathrm{a} \pm 1.16$ \\
WBA & $17.24 \mathrm{~b} \pm 0.86$ & $14.26 \mathrm{~b} \pm 1.42$ \\
SA & $21.24 \mathrm{a} \pm 1.21$ & $16.50 \mathrm{ab} \pm 2.32$ \\
\hline
\end{tabular}

- Within Columns, means with different alphabets are significantly different.

- I: Industrial, A: Anbaris, BH:Baalbek-Hermel; WB: Western Beqaa, S: Shouf
3.2.6 Fat on dry basis (FDM) and moistur on fat free basis (MFFB) of anbaris

There was no significant difference in the FDM value of anbaris from different regions and industrial origin. (Table 9). Furthermore, the MFFB of household anbaris from the Western Beqaa region was significantly the highest compared to the other household anbaris and comparable only to the MFFB value of anbaris from industrial origin. The MFFB of all of the other anbaris were comparable and did not differ significantly.

Table 9 Fat and protein content and pH of anbaris

\begin{tabular}{lcc}
\hline & Fat on Dry Basis & $\begin{array}{c}\text { Moisture on Fat Free } \\
\text { basis } \\
\text { Mean } \pm \text { SE }\end{array}$ \\
\hline IA & $54.93 \mathrm{a} \pm 2.19$ & $74.77 \mathrm{ab} \pm 1.66$ \\
BHA & $47.40 \mathrm{a} \pm 3.45$ & $72.54 \mathrm{~b} \pm 1.16$ \\
WBA & $51.09 \mathrm{a} \pm 4.10$ & $79.84 \mathrm{a} \pm 1.42$ \\
SA & $50.16 \mathrm{a} \pm 2.90$ & $70.05 \mathrm{~b} \pm 2.32$
\end{tabular}

- Within Columns, means with different alphabets are significantly different.

- I: Industrial, A: Anbaris, BH:Baalbek-Hermel; WB: Western Beqaa, S: Shouf

\subsection{Microbiology tests}

All industrial samples were compliant. As for the household anbaris 1 out of 30 had yeast and mold (Table 10).

\subsection{Correlation}

The ash content was only negatively and significantly with fat $(-0.40)$ and not significantly correlated with any of the other factors.

Water activity was only significantly and negatively correlated with total solids, titratable acidity, salt content and milk to anbaris conversion value. All the rest correlations being not significant. As for the total solid, it is significantly and positively correlated with salt content and highly correlated with protein content and milk to anbaris conversion value. Concerning the titratable acidity it is negatively and significantly correlated with $\mathrm{pH}$. In turn the $\mathrm{pH}$ is positively and significantly correlated with salt content (Table 11). 
Table 10 Microbiological tests complaince

\begin{tabular}{|c|c|c|}
\hline Microbiology tests & Industrial & Household \\
\hline Aerobic Plate Count & $\begin{array}{l}\text { All } \\
\text { Compliant }\end{array}$ & $\begin{array}{l}\text { All } \\
\text { Compliant }\end{array}$ \\
\hline Enterobacteriacae & $\begin{array}{l}\text { All } \\
\text { Compliant }\end{array}$ & $\begin{array}{l}\text { All } \\
\text { Compliant }\end{array}$ \\
\hline Coliforms & $\begin{array}{l}\text { All } \\
\text { Compliant }\end{array}$ & $\begin{array}{l}\text { All } \\
\text { Compliant }\end{array}$ \\
\hline E.coli & $\begin{array}{l}\text { All } \\
\text { Compliant }\end{array}$ & $\begin{array}{l}\text { All } \\
\text { Compliant }\end{array}$ \\
\hline S. aureus & $\begin{array}{l}\text { All } \\
\text { Compliant }\end{array}$ & $\begin{array}{l}\text { All } \\
\text { Compliant }\end{array}$ \\
\hline $\begin{array}{l}\text { Anaerobic } \\
\text { Sulfite/Reducing } \\
\text { Bacteria }\end{array}$ & $\begin{array}{l}\text { All } \\
\text { Compliant }\end{array}$ & $\begin{array}{l}\text { All } \\
\text { Compliant }\end{array}$ \\
\hline $\begin{array}{l}\text { Clostridium } \\
\text { perifringens }\end{array}$ & $\begin{array}{l}\text { All } \\
\text { Compliant }\end{array}$ & $\begin{array}{l}\text { All } \\
\text { Compliant }\end{array}$ \\
\hline Listeria monocytogens & $\begin{array}{l}\text { All } \\
\text { Compliant }\end{array}$ & $\begin{array}{l}\text { All } \\
\text { Compliant }\end{array}$ \\
\hline Salmonella & $\begin{array}{l}\text { All } \\
\text { Compliant }\end{array}$ & $\begin{array}{l}\text { All } \\
\text { Compliant }\end{array}$ \\
\hline Yeast and Molds & $\begin{array}{l}\text { All } \\
\text { Compliant }\end{array}$ & $\begin{array}{l}3.33 \% \\
\text { positive }\end{array}$ \\
\hline
\end{tabular}

Table 11 Partial Correlation part 1

\begin{tabular}{lcccc}
\hline & Aw & TS & TA\% & pH \\
\hline aw & & -0.38 & -0.73 & ns \\
TS & -0.38 & & ns & ns \\
TA\% & -0.73 & ns & & -0.50 \\
pH & ns & ns & -0.50 & \\
Salt\% & -0.31 & 0.27 & ns & 0.26 \\
Fat\% & Ns & ns & ns & ns \\
Prt\% & Ns & 0.79 & ns & ns \\
MACV & -0.38 & 0.80 & ns & ns \\
\hline
\end{tabular}

- Aw: Water activity; TS: Total solids; TA: Titratable acidity; Prt: Protein; MACV: milk to anbaris conversion value; ns: not significant

- Presence of number means $\mathrm{p}<0.05$

Salt is positively and significantly correlated with fat and protein content. It is also significantly and positively correlated with milk to anbaris conversion value. Fat is positively and significantly correlated with protein content. Protein in turn is highly, significantly and positively correlated with milk to cheese conversion value (Table 12). ISSN: 2456-1878
Table 12 Partial correlation part 2

\begin{tabular}{lcccc}
\hline & Salt & Fat & Prt\% & $\begin{array}{c}\text { MAC } \\
\text { V }\end{array}$ \\
\hline aw & -0.31 & ns & ns & -0.38 \\
TS & 0.27 & ns & 0.79 & 0.80 \\
TA\% & ns & ns & ns & ns \\
pH & 0.26 & ns & ns & ns \\
Salt\% & & 0.45 & 0.26 & 0.27 \\
Fat\% & 0.45 & & 0.31 & ns \\
Prt\% & 0.26 & 0.31 & & 0.79 \\
MACV & 0.27 & ns & 0.79 & \\
\hline
\end{tabular}

- Aw: Water activity; TS: Total solids; TA: Titratable acidity; Prt: Protein; MACV: milk to anbaris conversion value; ns: not significant

- Presence of number means $\mathrm{p}<0.05$

\section{DISCUSSION}

There is a need to identify and classify the bacteria used in anbaris production since until now they use part of old anbaris as the inoculum for further fermentation. There was a study conducted by Dib et al, 2012, where they isolated and identified twenty five strains, where nine of them belong to Lactobacillus plantarum, three are Lactobacillus paracasei spp. paracasei and five are Leuconostoc mesenteroides spp. dextranicum 2; four are Lactobacillus casei and four others are yeasts [30]. Thus, they have only screened the microbiota found in the end product and not the optimum proportions of the different bacteria. The use of raw milk, like in anbaris production, is not that common in the production of fermented milk products [31].

As for the water activity the lowest one was of 0.954 and $\mathrm{pH}$ was around 3.8 thus it is a very high acid food [32]. This makes anbaris in the food category that is easier to preserve against bacterial deterioration. Furthermore, anbaris is peculiar since it follows fermentation of raw milk and thus unlike normal labneh where heat treatment is essential, which might explain the non smooth texture of it compared to the smooth creamy taste of labneh which needs further investigation.

The moisture content of the anbaris from Western Beqaa was significantly the highest, which was also reflected by the milk to anbaris conversion values, which was the lowest, meaning less $\mathrm{kg}$ of milk was needed to produce one $\mathrm{kg}$ of anbaris. This might also explain why the anbaris sample that had yeast and mold content did come from that 
district. As for the compliance of all samples with the bacterial tests (Table 10) it might be explained by the finding of Dib et al. where he mentioned that the identified strains showed an ability to produce antimicrobial substances with maximum inhibition diameters of $20 \mathrm{~mm}$ against Salmonella, $21 \mathrm{~mm}$ and $19 \mathrm{~mm}$ against Escherichia coli and Staphylococcus aureus, respectively [30].

The milk to anbaris conversion values, as expected, were positively related to total solid, salt and protein content and negatively correlated with water activity [33]. It would be interesting to study the relationship between the different milk component and that of anbaris yield similar the study conducted by Zeng et al. who proposed equations for cheese yield based on milk components [34].

To classify cheese according to the codex standard DFM and MFFB were calculated. Anbaris can be classified as full fat dairy product since content of FDM is above or equal to $45 \%$ and less than $60 \%$. As for the MFFB anbaris is classified as soft since it is larger than $67 \%$ [18] [35]. As for the curing classification: it is fermented type, but concerning the curing it is very special where it is not cured in the normal sense. Anbaris is uncured since we can consume it directly after $7-15$ days, but in reality the whey is strained from the earthen-ware and milk and salt is added repeatedly until it is full $[9,10]$. Finally since it is from raw milk, anbaris can be produced from leftover milk or milk with $\mathrm{pH}$ at 6.4 or a bit lower which is out of the normal $\mathrm{pH}$ range of milk [36].

\section{CONCLUSION}

Anbaris is a special type of full fat, soft, cheese like fermented cheese from raw milk with a $\mathrm{pH}$ lower than 4 . It has a special feature since it is fermented, whey strained, milk and salt added then continues fermentation. It is relatively safe against bacterial contamination, yeast and mold however might grow especially if high moisture content anbaris is produced. It can be used to reduce wastage of extra milk or milk that have reached 6.4 in $\mathrm{pH}$ thus out of the normal range.

\section{REFERENCES}

[1] Tamime, AY. (2002). Fermented milks: a historical food with modern applications-a review. European Journal of Clinical Nutrition, 56(4), S2-S15.

[2] Caplice, Elizabeth and Fitzgerald, Gerald F. (1999). Food fermentations: role of microorganisms in food production and preservation. International journal of food microbiology, 50(1-2), 131-149.
[3] Tamime, AY, Wszolek, Monika, Božanić, Rajka, and Özer, Barbaros. (2011). Popular ovine and caprine fermented milks. Small Ruminant Research, 101(1-3), 2-16.

[4] Ayar, Ahmet and Gurlin, Esra. (2014). Production and sensory, textural, physicochemical properties of flavored spreadable yogurt. Life Science Journal, 11(4), 58-65.

[5] Tamime, Adnan Y and Robinson, Richard Kenneth. (2007). Tamime and Robinson's yoghurt: science and technology: Elsevier.

[6] Özer, B. (2006). Production of concentrated products. Fermented milks, 128-155.

[7] Keceli, Turkan, Robinson, RK, and Gordon, MH. (1999). The role of olive oil in the preservation of yogurt cheese (labneh anbaris). International journal of dairy technology, 52(2), 68-72.

[8] Al-Kadamany, E, Toufeili, I, Khattar, M, Abou-Jawdeh, Y, Harakeh, S, and Haddad, T. (2002). Determination of shelf life of concentrated yogurt (Labneh) produced by in-bag straining of set yogurt using hazard analysis. Journal of dairy science, 85(5), 1023-1030.

[9] Saleh, Hassan, Microbiological changes, chemical composition and sensory properties of Labneh anbaris made from cow's and goat's milk-by Hassan Saleh. 1991.

[10] Serhan, Mireille and Mattar, Jessy. (2013). Characterization of four Lebanese artisanal goat milk cheeses: Darfiyeh, Aricheh, Shankleesh and Serdale by physico-chemical, microbiological and sensory analyses. J. Food Agric. Environ, 11(3-4), 97-101.

[11] Barakat, Darine Emile, The effect of heat treatment and storage temperature on the microbiological and chemical qualities of traditional Labneh anbris-by Darine Emile Barakat. 2009.

[12] IDICO. Directory of exports and industrial firms in Lebanon (2018-2019). 2019; 10:[Available from: https://www.lebanon-industry.com/industrial-sector/8\#grid.

[13] ISO5537, Dried milk - Determination of moisture content (Reference method), in ICS > $07>07.100>07.100 .30$, International Organization for Standardization; Editor. 2004: Geneva, Switzerland: .

[14] AOAC. (1990). 15th Edition, Association of Official Analytical Chemists, Washington DC.

[15] ADMI, Chicago. (1971). Standards for Grades of Dry Milk including Methods of Analysis. Bulletin, 916.

[16] KJ Valentas, E Rotstein, RP Singh (1997). Handbook of food engineering practice: $\mathrm{CRC}$ press.

[17] Nielsen, S Suzanne, Sodium Determination Using IonSelective Electrodes, Mohr Titration, and Test Strips, in Food Analysis Laboratory Manual. 2017, Springer. p. 161170.

[18] Commission, Codex Alimentarius. (2006). Codex General Standard for Cheese: CODEX STAN A-6-1978. 26th Session FAO/WHO Food Standards Programme.

[19] ISO4833, Microbiology of the food chain - Horizontal method for the enumeration of microorganisms - Part 1: Colony count at 30 degrees $\mathrm{C}$ by the pour plate technique, in ICS > $07>07.100>07.100 .30$, International Organization for Standardization; Editor. 2016: Geneva, Switzerland: . 
[20] ISO21528-2, Microbiology of food and animal feeding stuffs - Horizontal methods for the detection and enumeration of Enterobacteriaceae - Part 2: Colony-count method, in ICS $>07>07.100>07.100 .30$, International Organization for Standardization; , Editor. 2017: Geneva, Switzerland: .

[21] ISO4832, Microbiology of food and animal feeding stuffs Horizontal method for the enumeration of coliforms Colony-count technique, in ICS > $07>07.100>07.100 .30$, International Organization for Standardization; Editor. 2006: Geneva, Switzerland: .

[22] ISO16649-2, Microbiology of food and animal feeding stuffs - Horizontal method for the enumeration of betaglucuronidase-positive Escherichia coli - Part 2: Colonycount technique at 44 degrees $\mathrm{C}$ using 5-bromo-4-chloro-3indolyl beta-D-glucuronide, in ICS > $07>07.100>$ 07.100.30, International Organization for Standardization; Editor. 2001: Geneva, Switzerland:

[23] ISO6888-1, Microbiology of food and animal feeding stuffs - Horizontal method for the enumeration of coagulasepositive staphylococci (Staphylococcus aureus and other species) - Part 1: Technique using Baird-Parker agar medium, in ICS > $07>07.100>07.100 .30$, International Organization for Standardization; Editor. 1999: Geneva, Switzerland:

[24] ISO15213, Microbiology of food and animal feeding stuffs - Horizontal method for the enumeration of sulfitereducing bacteria growing under anaerobic conditions, in ICS > $07>07.100>07.100 .30$, International Organization for Standardization; , Editor. 2003: Geneva, Switzerland: .

[25] ISO7937, Microbiology of food and animal feeding stuffs Horizontal method for the enumeration of Clostridium perfringens - Colony-count technique, in ICS > $07>$ $07.100>07.100 .30$, International Organization for Standardization; , Editor. 2004: Geneva, Switzerland: .

[26] ISO11290-1, Microbiology of the food chain - Horizontal method for the detection and enumeration of Listeria monocytogenes and of Listeria spp. - Part 1: Detection method, in ICS > $07>07.100>07.100 .30$, International Organization for Standardization; Editor. 2017: Geneva, Switzerland:

[27] ISO6579-1, Microbiology of the food chain - Horizontal method for the detection, enumeration and serotyping of Salmonella - Part 1: Detection of Salmonella spp., in ICS > $07>07.100>07.100 .30$, International Organization for Standardization; Editor. 2017: Geneva, Switzerland:.

[28] ISO6611, Milk and milk products - Enumeration of colony-forming units of yeasts and/or moulds - Colonycount technique at 25 degrees $\mathrm{C}$, in ICS > $07>07.100>$ 07.100.30, International Organization for Standardization; Editor. 2004, Iso: Geneva, Switzerland:.

[29] Blominvest-bank. Lebanese Dairy Sector 2016; 10:[Available from: https://blog.blominvestbank.com/wpcontent/uploads/2016/05/Lebanese-Dairy-Sector2.pdf.

[30] Dib, H, Hajj Semaan, E, Mrad, R, Ayoub, J, Choueiry, L, Moussa, H, and Bitar, G. (2012). Identification et évaluation de l'effet probiotique des bactéries lactiques isolées dans des fromages caprins traditionnels. Lebanese Science Journal, 13(1), 43-48.

[31] Patel, Dilip and Walker, Marcia. (2004). Semisolid Cultured Dairy Products: Principles and Applications. FOOD SCIENCE AND TECHNOLOGY-NEW YORK-MARCEL DEKKER-, 113-124.

[32] Food, US and Administration, Drug. (2018). Title 21-food and drugs chapter 1-Food and Drug Administration Department of Health and Human Services Subchapter Ddrugs for human use. Available from. 21US Food and Drug Administration. Title.

[33] Dimassi, O, Hinrichs, J, and Zárate, A Valle. (2006). Cheese production potential of milk from Dahlem Cashmere goats using a cheese simulation method. Small Ruminant Research, 65(1-2), 38-43.

[34] Zeng, SS, Soryal, K, Fekadu, B, Bah, B, and Popham, T. (2007). Predictive formulae for goat cheese yield based on milk composition. Small ruminant research, 69(1-3), 180186.

[35] TetraPak-a, Cheese in Dairy Processing Handbook. 2015, Tetra Pak. p. 301-304.

[36] TetraPak-b, The chemistry of milk, in Dairy Processing Handbook. 2015, Tetra Pak. p. 301-304. 